\title{
MOLECULAR, RADIOACTIVE AND STABLE CARBON ISOTOPE CHARACTERIZATION OF ESTUARINE PARTICULATE ORGANIC MATTER
}

\author{
LUC MEGENS, ${ }^{1,2}$ JOHANNES VAN DER PLICHT ${ }^{1}$ and JAN W. DE LEEUW ${ }^{2}$
}

\begin{abstract}
Organic matter in sediments and suspended matter is a complex mixture of constituents with different histories, sources and stabilities. To study these components in a suspended matter sample from the Ems-Dollard Estuary, we used combined molecular analysis with pyrolysis/gas chromatography/mass spectrometry and stable and radioactive carbon isotope analyses of the bulk and separated chemical fractions. Carbohydrates and proteins, ca. 50\% of the total organic carbon (TOC), are much younger than the bulk sample and have a somewhat higher $\delta^{13} \mathrm{C}$ value. Lipids and the final residue are considerably older and have lower $\delta^{13} \mathrm{C}$ values. The final residue, ca. $17 \%$ of the total carbon, consists mainly of aliphatic macromolecules that could be derived from algae or terrestrial plants. The $\delta^{13} \mathrm{C}$ value points to a marine origin.
\end{abstract}

\section{INTRODUCTION}

Organic matter (OM), in the form of sediments (SOM) and suspended matter (POM), is a complex mixture of constituents with different histories, sources and stabilities. Therefore, these constituents can also differ in age so that ${ }^{14} \mathrm{C}$ dating of SOM and POM will give an average age of the contributing organic components instead of a date of sedimentation. Fractionation of the $\mathrm{OM}$ and successive complementary molecular and isotopic analyses of these fractions will, however, be useful to differentiate sources, histories and stabilities of these fractions and thus of SOM and POM as a whole.

POM in estuaries is derived from local primary production and transported material, both marine and terrestrial. Sources of the marine component can be primary production or eroded sediment; those of the terrestrial component can be eroded soil or peat. To discriminate the terrestrial from the marine organic component, many researchers use a linear mixing model based on the difference in the ${ }^{13} \mathrm{C} /{ }^{12} \mathrm{C}$ ratio between marine phytoplankton and terrestrial plants (e.g., Laane et al. 1990). OM derived from marine phytoplankton-the main source of marine organic matter-has $\delta^{13} \mathrm{C}$ values of ca. $-21 \%$, while terrestrial organic matter derived from $\mathrm{C}_{3}$ plants has $\delta^{13} \mathrm{C}$ values of $c a .-27 \%$ (Mook and Tan 1991).

Sometimes this straightforward two-ended mixing model works nicely, but there are some complicating factors: $\delta^{13} \mathrm{C}$ values of marine phytoplankton can vary from -16 to $-27 \%$ (Sackett $e$ al . 1965; Fontugne and Duplessy 1981), depending on environmental factors such as temperature, light intensity, salinity and nutrient availability. Secondly, OM from one organism is nevertheless a mixture of different compounds covering a wide range of $\delta^{13} \mathrm{C}$ values. Polysaccharides and proteins have on average higher $\delta^{13} \mathrm{C}$ values than lipids (Deines 1980). The $\delta^{13} \mathrm{C}$ values of amino acids from one organism can cover a range of $>10 \%$ (Macko et al. 1994) and also lipids from one organism show large differences in $\delta^{13} \mathrm{C}$ (Schouten et al. ms.). Third, in most cases, POM represents only a fraction of the original biomass. Polysaccharides and proteins are much more labile than some lipids and other bio(macro)molecules. Because of the differences in $\delta^{13} \mathrm{C}$ between these molecules, this selective degradation will affect the total $\delta^{13} \mathrm{C}$ value as well. Combining the results of stable carbon isotope analysis with ${ }^{14} \mathrm{C}$ measurements of quantified well-characterized fractions of POM might be helpful in a validation of the processes and variables determining the molecular and isotopic composition of the POM. Such an approach was followed by Wang et al. (1996) for tracing the origin and history of POM and SOM in the deep ocean. Their results show large differences in ${ }^{14} \mathrm{C}$ activi-

\footnotetext{
${ }^{1}$ Center for Isotope Research, University of Groningen, Nijenborgh 4, 9747 AG Groningen, the Netherlands

${ }^{2}$ Department of Marine Biogeochemistry and Toxicology, Netherlands Institute for Sea Research, PO Box 59, $1790 \mathrm{AB}$ Texel, the Netherlands
} 
ties and $\delta^{13} \mathrm{C}$ in fractions of SOM and POM, suggesting preferential decomposition of OM and adsorption of old dissolved organic matter. To establish the origin and history of estuarine POM, we analyzed bulk and chemical fractions of POM from the Ems-Dollard Estuary, combining isotopic and molecular analyses and investigating whether the phenomena found by Wang et al. (1996) in deep ocean POM and SOM can also be found in estuarine POM.

\section{METHODS}

\section{Samples}

Samples of suspended matter from the Ems-Dollard Estuary, bordering the Netherlands, Germany and the North Sea, were obtained from Dr. F. Smedes of the National Institute for Coastal and Marine Management (RIKZ) in Haren, the Netherlands. The analyzed sample was taken on August 12,1993 by continuous-flow centrifugation during a 2-h period. $\mathrm{Ca} .1900 \mathrm{~L}$ of water was centrifuged from $1.5-\mathrm{m}$ depth. The resulting POM sample was freeze-dried. The sampling area is shown in Figure 1; the sampling station (indicated by the letter E) is near the Dutch town of Delfzijl.

Fig. 1. Sample area of the suspended matter sample.

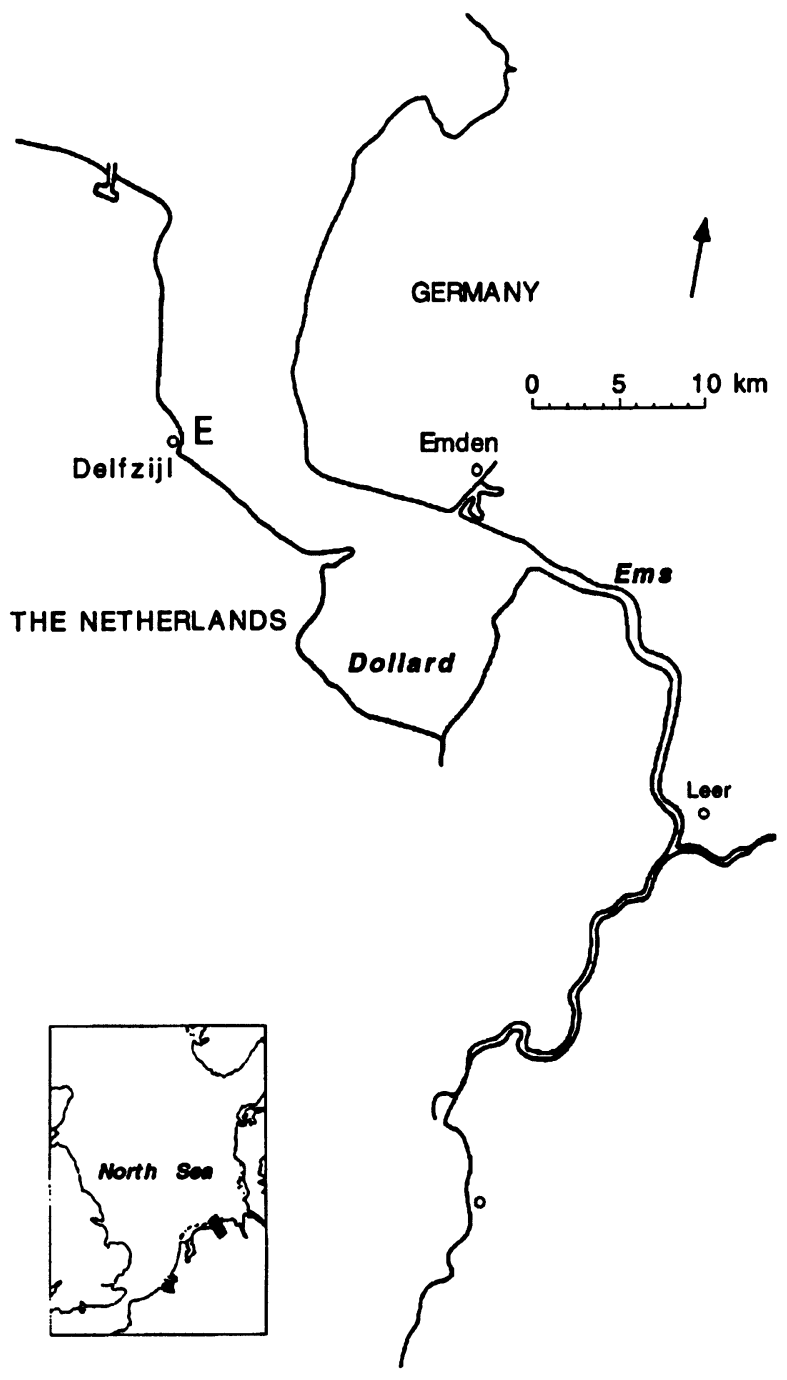




\section{Extraction Procedure}

We used analytical-grade solvents and chemicals. The water used was produced by a Millipore milli-Q apparatus. The extraction procedure was based in part on the work of Klok et al. (1981a, 1984). First, samples were extracted by refluxing for $24 \mathrm{~h}$ with water. The residue and extract were freeze-dried. Then, contrary to the procedure of Klok et al., we hydrolyzed the residue with $1 \mathrm{M}$ $\mathrm{H}_{2} \mathrm{SO}_{4}$ at $100^{\circ} \mathrm{C}$ over a period of $3 \mathrm{~h}$ to remove carbohydrates that were not extracted with hot water. This step was inserted to avoid condensation reactions of sugars with amino acids during the $\mathrm{HCl}$ treatment. The extract was neutralized with $\mathrm{BaCO}_{3}$, filtered over a glass filter and freeze-dried (Klok et al. 1981b). The residue was washed with water and freeze-dried. This residue was hydrolyzed with $6 \mathrm{M} \mathrm{HCl}$ for $24 \mathrm{~h}$ at $100^{\circ} \mathrm{C}$. The extract was dried in vacuo over $\mathrm{KOH}$, and the residue was washed with water and freeze-dried and subsequently extracted ultrasonically with a $2: 1 \mathrm{mix}-$ ture of chloroform : methanol. The residue and extract were dried under a gentle stream of nitrogen at $30^{\circ} \mathrm{C}$. The last step was treatment with $1 \mathrm{M} \mathrm{KOH}$ at $100^{\circ} \mathrm{C}$ for $1 \mathrm{~h}$. The liquid phase was removed by centrifugation and the residue washed repeatedly with water. The supernatants were extracted with chloroform and the extract was dried under nitrogen.

Alternatively, the sample was first 3 times ultrasonically extracted with chloroform : methanol (2:1). The extract and residue were dried under a stream of nitrogen. Then the residue was either treated with $1 \mathrm{M} \mathrm{KOH}$ at $100^{\circ} \mathrm{C}$ for $1 \mathrm{~h}$ or extracted with boiling water for $24 \mathrm{~h}$ (vide supra). An aliquot from all the intermediate residues was taken for analysis.

\section{Analysis}

Samples containing carbonates were treated with dilute hydrochloric acid and dried in vacuo over $\mathrm{KOH}$. Samples were combusted for $6 \mathrm{~h}$ at $600^{\circ} \mathrm{C}$ in evacuated sealed quartz tubes with copper oxide as an oxidator. The resulting gas was purified with a dry ice : ethanol cold trap to remove water and a silver oven at $400^{\circ} \mathrm{C}$ to remove halogens and sulfur compounds. The purified carbon dioxide was analyzed for $\delta^{13} \mathrm{C}$ with a VG SIRA 9 isotope ratio mass spectrometer. $\delta^{13} \mathrm{C}$ values are reported relative to the V-PDB standard. The $\mathrm{CO}_{2}$ was reduced to graphite with iron as a catalyst at $600^{\circ} \mathrm{C}$ as described by Aerts-Bijma et al. (1997) and analyzed for ${ }^{14} \mathrm{C}$ concentration with the Groningen ${ }^{14} \mathrm{C}$ AMS (Gottdang et al. 1996). Results were reported as ${ }^{14} \mathrm{a}$ in percent of modern carbon (pMC).

Molecular analysis was performed using online pyrolysis gas chromatography-mass spectrometry as described by van Heemst $e t$ al. (ms.). The sample is pressed on a wire with a curie point of $610^{\circ} \mathrm{C}$ and placed in a pyrolysis unit mounted on a gas chromatograph. The wire was heated under nitrogen by induction with a high-frequency field. Pyrolysis products are led into the GC column. The GC is connected to a mass spectrometer that measures spectra of the separated compounds.

\section{RESULTS AND DISCUSSION}

The POM sample from the Ems-Dollard was fractionated according to the procedure shown in Figure 2. The thus-obtained fractions were analyzed molecularly and isotopically. Py-GC-MS analysis of fractions E1, E2 and R5 showed that the hot water extract (E1) consisted mainly of (poly)saccharides and some protein (cf., Klok et al. 1981a, 1984). The extract after hydrochloric acid treatment (E3) was derived from hydrolyzed protein. The pyrolysate of the final residue contained mainly homologous series of $n$-alkanes and $n$-alkenes (Fig. 3). This material might be derived from algaenans or cutans, resistant aliphatic biopolymers from respectively plant cuticles or algal cell walls (de Leeuw et al. 1991). Sulfuric acid hydrolysis (E2) is a standard method to hydrolyze polysaccharides. E4 is the "free" lipid fraction and E5 probably contains saponified lipids and alkali soluble material. 


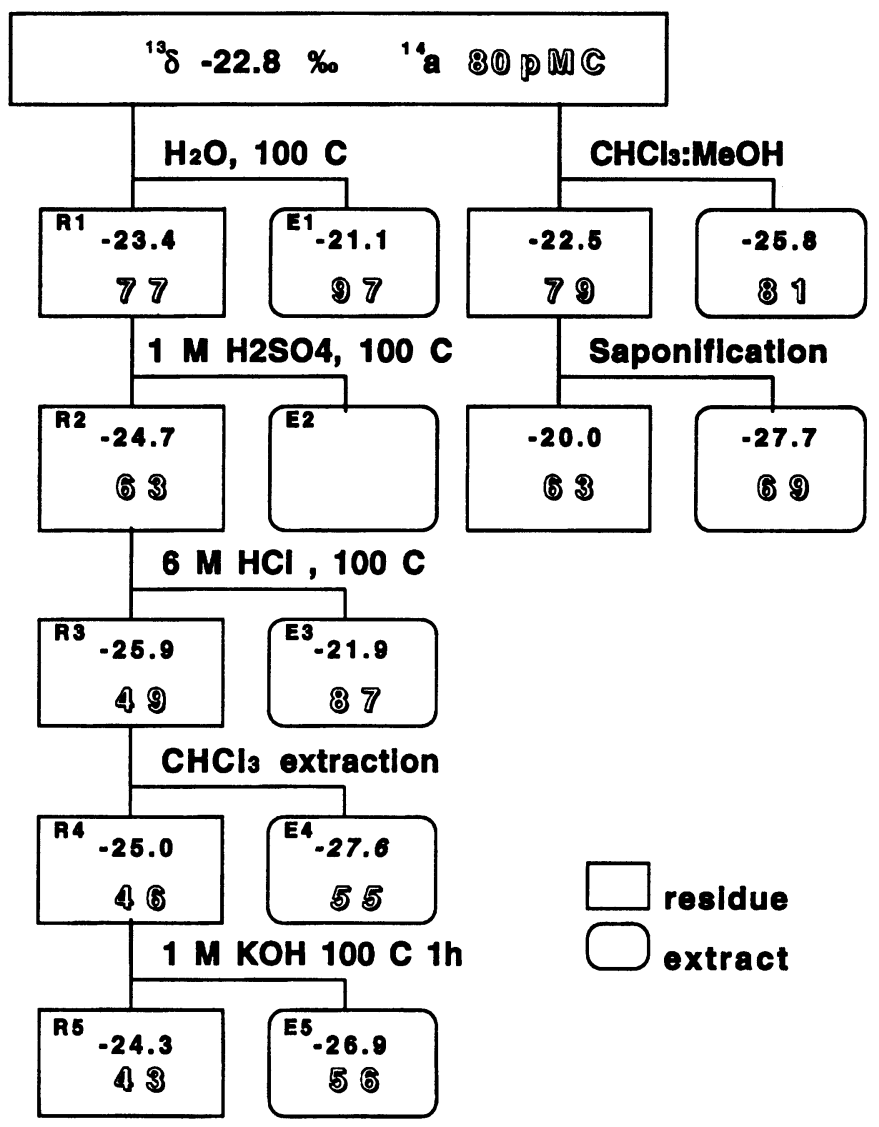

Fig. 2. Scheme of the extraction procedure. $R=$ residue; $E=$ extract. See text for chemical identification.

A carbon balance was made based on the weights of the fractions and their organic carbon concentrations. Ca. 50\% of the total organic carbon was extracted in the first three fractions as (poly)saccharides and protein. The final residue accounted for $c a .17 \%$ of the total organic matter. Isotopic analyses showed a considerable variation in the $\delta^{13} \mathrm{C}$ values and ${ }^{14} \mathrm{C}$ activities (Fig. 2) The polysaccharides and proteins have considerably higher ${ }^{14} \mathrm{C}$ activities than the bulk sample. These compounds can be degraded rapidly by microorganisms in the water column (Deines 1980; Laane et al. 1990), so only relatively fresh material is present. The sulfuric acid extract could not be analyzed, probably because of the presence of too much sulfur oxide in the gas mixture. The residual organic material has a much lower ${ }^{14} \mathrm{C}$ activity. This indicates a highly resistant nature of this material ( $c f$. de Leeuw et al. 1991).

The lipids extracted in this procedure have a much lower ${ }^{14}$ a value (56 pMC) than lipids extracted directly from the untreated sample $\left({ }^{14} \mathrm{a}: 81 \mathrm{pMC}\right)$. Moreover, these fractions differ in $\delta^{13} \mathrm{C}(-27.6 \mathrm{vs}$. $-25.8 \%$ ). Perhaps the youngest lipids were extracted in the previous treatments. When the hot water extraction and the $\mathrm{HCl}$ hydrolysis are performed after extraction of lipids, their $\delta^{13} \mathrm{C}$ values are slightly higher ( 0.6 and $0.9 \%$ for the hot water and $\mathrm{HCl}$ extract, respectively). This could indicate that they contain some lipids, since lipids have lower $\delta^{13} \mathrm{C}$ values than carbohydrates and amino acids. However, lipids could not be extracted from the other extracts. 


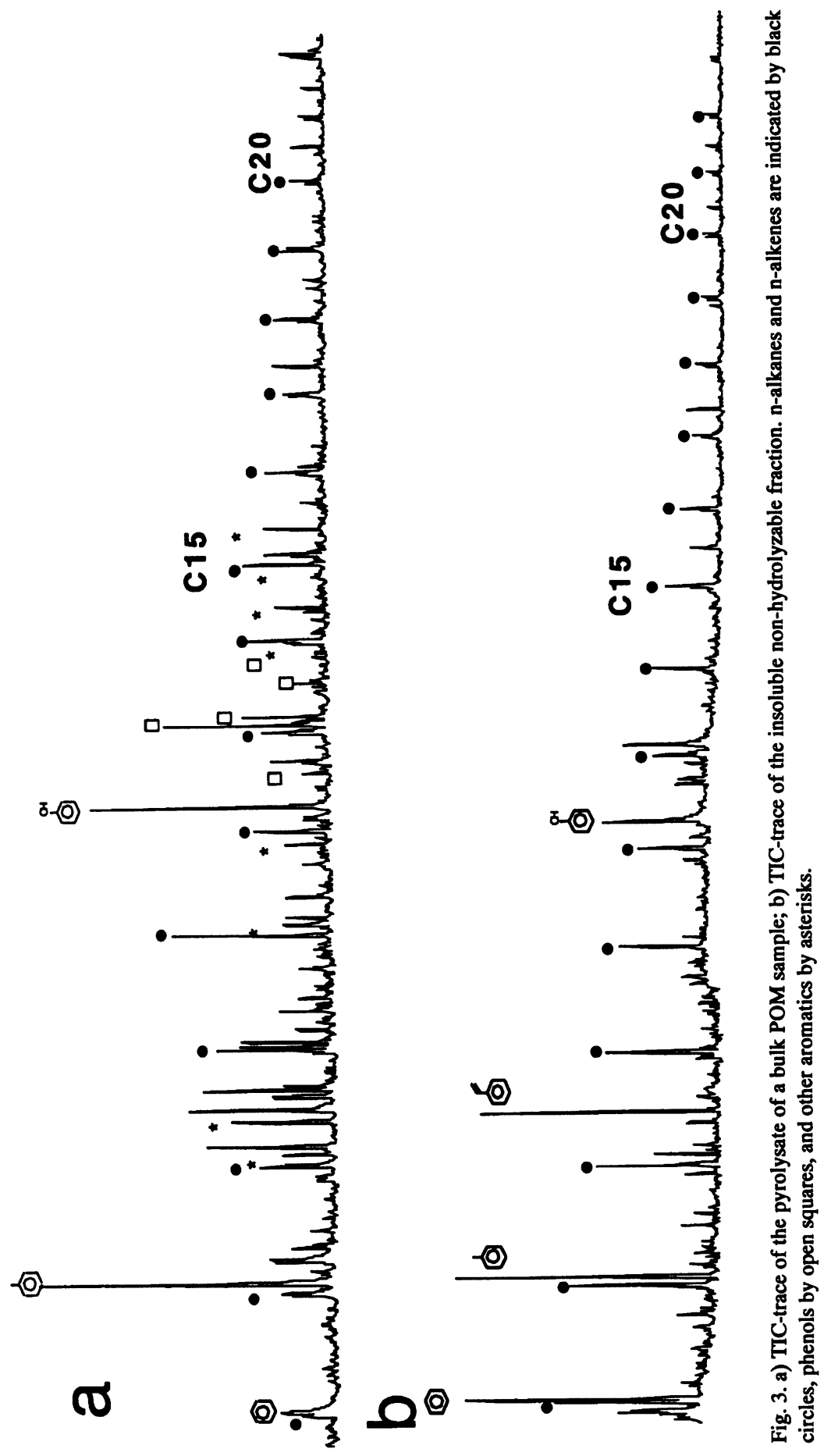


Mass balances calculated with ${ }^{14} \mathrm{a}, \delta^{13} \mathrm{C}$ and organic carbon yields are in good agreement with each other, which indicates that the extraction procedure yields valid results.

\section{CONCLUSION}

Chemical fractions of POM from the Ems-Dollard estuary show considerable differences in their ${ }^{14} \mathrm{a}$ and $\delta^{13} \mathrm{C}$ values. Carbohydrates and amino acids have higher ${ }^{14} \mathrm{a}$ values and are lighter in ${ }^{13} \mathrm{C}$ than the bulk sample. The insoluble unhydrolyzable residue has a much lower ${ }^{14} \mathrm{a}$ value than the bulk. It has a highly aliphatic macromolecular nature. It may be derived from aliphatic biopolymers from the cell walls of algae or from terrestrial plant cuticles. $\delta^{13} \mathrm{C}$ values of the fractions indicate a mainly marine algal origin.

\section{REFERENCES}

Aerts-Bijma, A. Th., Meijer, H. A. J. and van der Plicht, J. 1997 AMS sample handling in Groningen. Nuclear Instruments and Methods in Physics Research B123 221-225.

Deines, P. 1980 The isotopic composition of reduced organic carbon. In Fritz, P. and Fontes, J.-Ch., eds., Handbook of Environmental Isotope Geochemistry. Volume 1. The Terrestrial Environment. Part A. Amsterdam, Elsevier: 329-406.

de Leeuw, J. W., van Bergen, P. F., van Aarssen, B. G. K., Gatellier, J. P. L. A., Sinninghe Damsté, J. S. and Collinson, M. E. 1991 Resistant biomacromolecules as major contributors to kerogen. Philosophical Transactions, Royal Society of London B333: 329-337.

Fontugne, M. R. and Duplessy, J. C. 1981 Organic carbon isotope fractionation by marine plankton in the temperature range -1 to $31^{\circ} \mathrm{C}$. Oceanologica Acta $4: 85-$ 90.

Gottdang, A., Mous, D. J. W. and van der Plicht, J. 1995 The HVEE ${ }^{14} \mathrm{C}$ system at Groningen. In Cook, G. T., Harkness, D. D., Miller, B. F. and Scott, E. M., eds., Proceedings of the 15 th International ${ }^{14} \mathrm{C}$ Conference. Radiocarbon 37(2): 649-656.

van Heemst, J. D. H., Megens, L., de Leeuw, J. W. and Hatcher, P. G. (ms.) Characterisation of estuarine macromolecular dissolved organic matter. Submitted to Limnology and Oceanography.

Klok, J., van der Knaap, J. M. M., de Leeuw, J. W., Cox, H. C. and Schenck, P. A. 1981a Qualitative and quantitative characterization of the total organic matter in a recent marine sediment. In Bjoroy, M. et al., eds., Advances in Organic Geochemistry 1981. Oxford, Pergamon: 813-818.

Klok, J., Nieberg-van Velzen, E. H., de Leeuw, J. W. and Schenck, P. A. 1981b Capillary gas chromatographic separation of monosaccharides as their alditol ace- tates. Journal of Chromatography 207: 273-275.

Klok, J., Baas, M., Cox, H. C., de Leeuw, J. W., Rijpstra, W. I. C. and Schenck, P. A. 1984 Qualitative and quantitative characterization of the total organic matter in a recent marine sediment. Organic Geochemistry 6: 265-278.

Laane, R., Turkstra, E. and Mook, W. 1990 Stable carbon isotope composition of pelagic and benthic organic matter in the North Sea and adjacent estuaries. In Ittekot, V., Kempe, S. Michaelis, W., and Spitzy, A., eds., Facets of Modern Biogeochemistry. BerlinHeidelberg, Springer Verlag: 214-224.

Macko, S. A., Engel, M. H. and Qiang, Y. 1994 Early diagenesis and organic matter preservation - a molecular stable carbon isotope perspective. Chemical Geology 114: 365-379.

Mook, W. G. and Tan, F. C. 1991 Stable carbon isotopes in rivers and estuaries. In Degens, E. T., Kempe, S. and Richie, J. E., eds., Biogeochemistry of Major World Rivers. SCOPE Report 42. New York, John Wiley \& Sons: 245-264.

Sackett, W. M., Eckelman, W. R., Bender, M. L. and Be, A. W. H. 1965 Temperature dependence of carbon isotope composition in marine plankton and sediments. Science 148: 235-237.

Schouten, S., Klein Breteler, W., Blokker, P., Schogt, N., Rijpstra, W. I. C., Grice, K., Baas, M. and Sinnighe Damsté, J. S. (ms.) Biosynthetic effects on the stable isotope composition of algal lipids: Implications for deciphering the carbon-isotopic biomarker record. Submitted to Geochimica et Cosmochimica Acta.

Wang, X. C., Druffel, E. R. M. and Lee, C. 1996 Radiocarbon in organic compound classes in particulate organic matter and sediment in the deep northeast $\mathrm{Pa}$ cific Ocean. Geophysical Research Letters 23: 35833586. 